\title{
Audit committee quality and audit report lag: the role of mandatory adoption of IFRS in Saudi companies
}

\author{
Mahfod Mobarak Aldoseri ${ }^{\mathrm{a}}$, Nasr Taha Hassan ${ }^{\mathrm{a}}$ and Magdy Melegy Abd El Hakim Melegy ${ }^{\mathrm{b}^{*}}$
}

${ }^{a}$ Prince Sattam Bin Abdulaziz University, Community College, Saudi Arabia

${ }^{b}$ Benha University, Faculty of Commerce, Egypt

\begin{tabular}{l}
\hline C H R O N I C L E \\
\hline Article history: \\
Received: April 28, 2020 \\
Received in revised format: \\
July 30 2020 \\
Accepted: September 25, 2020 \\
Available online: \\
September 25, 2020 \\
\hline Keywords: \\
IFRS \\
Audit committee quality \\
Audit report lag \\
Saudi environment \\
Timeliness
\end{tabular}

\section{A B S T R A C T}

\begin{abstract}
This paper aims to examine the effect of audit committee characteristics on audit report lag, and also explores whether this effect will vary between before and after mandatory adoption of IFRS in Saudi listed companies. Based on a Saudi sample of 388 firm-year observations from 2015 to 2018, the Poisson regression analysis shows that among audit committee characteristics, only audit committee financial experience significantly influences the timing of financial reporting. The result indicates a weak influence of audit committees on timeliness of financial reporting, which is consistent with the results of most of previous studies. On the other hand, the results show a strong impact of the adoption of IFRS on the context of that relationship, where the results show the impact of IFRS on audit report lag, audit committee quality and the association between them.
\end{abstract}

\section{Introduction}

(C) 2021 by the authors; licensee Growing Science, Canada

A fundamental change was taken place in Saudi business environment in 2017, where IFRS has been mandatory adopted by all listed Saudi companies. IFRS is the most significant change in the financial reporting process in recent decades, and it is expected to affect the different dimensions of this process and the relationships between the different variables within it. In this context, on one hand, the audit report is of great importance to the quality of the financial reporting and the timing of its issuance is the determining factor for the timeliness of financial information, so the audit report lag received great attention from regulators and researchers. On the other hand, the Audit Committee is the most related governance mechanism to the financial reporting process, and it is expected to facilitate the work of the auditor, so the characteristics of the quality of this committee and its impact on the audit report delay received the attention of regulators and researchers. In spite of the increasing importance of timelines for regulators and researchers, there is limited or no attention given to explore the relation between audit report lag, audit committee and IFRS (Mohammed et al., 2018). Therefore, in the context of assessment the impact of IFRS adoption on financial reporting process in Saudi companies, the current study is concerned with the relationship between IFRS, the audit committee quality and the audit report lag. This paper examines the impact of quality characteristics of audit committees on the completion of the audit process, and explore whether that influence will differentiate between before and after the mandatory adoption of IFRS. Timeliness is considered an important characteristic of the information quality, where it is considered to be a critical and important factor affecting the usefulness of information made available to external users (Almosa \& Alabbas, 2008). The audit delay is the most influential factor in the timeliness of financial statements (Owusu-Ansah, 2000), and one of the factors that affect the audit efficiency (Habib, 2015), so it continues to attract the attention of researchers to identify the

* Corresponding author.

E-mail address: magdy.malagy@fcom.bu.edu.eg (M. M. A. E. H. Melegy) 
determinants of audit lag (Ettredge et al. 2006; Bonson-Ponte et al., 2008; Al-Ajmi, 2008; Lee et al. 2008, 2009; Afify, 2009; Krishnan \& Yang, 2009; Chan et al., 2016; Sharma et al., 2017; Rusmin \& John, 2017; Khoufi, \& Khoufi, 2018; Habib \& Muhammadi, 2018; Habib et al. 2019; Durand, 2019 ). All of corporate governance guides through over the world and the audit literature have identified the role of audit committee in oversight the financial reporting process, and assist external auditors to perform their duties. There is a worldwide trend to strengthen governance systems, and the main concern for this change is to improve the role of the Audit Committee in the context of the financial reporting quality and oversight the audit process (Baatwah et al., 2019). So, the current paper addresses the association between audit report lag and audit committee' characteristics in Saudi environment.

In addition, the adoption of IFRS is considered to be a significant change in the financial reporting environment (Musa, 2019), and the impact of IFRS on the accounting and audit quality attracts much attention. There are different opinions concerning the impact of IFRS on audit issues, Odia and Ogiedu (2013) argued that IFRS will maximise the audit quality, otherwise, Pope and McLeay, (2011) argued that IFRS increases the auditing cost that adversely affect audit process. The transition to IFRS poses challenges for companies and auditors (Amirul \& Md Salleh, 2014), where IFRS is considered to be complex and require detailed disclosure (Najihah \& Ayoib, 2011). Consequently, the adoption of IFRS could increase audit report lag. Emadfallatah, et al. (2019) reviewed empirical studies concerning the adoption of IFRS and audit issues, and they indicated that IFRS lead to increase the auditor report lag in developing countries. Given the importance of both audit committee and audit report lag in the context of audit and financial reporting process, it is important to explore whether the adoption of IFRS influence the audit committee quality and audit report lag and their association. The result of that examination provides useful insights on how the adoption of IFRS could improve the efficiency of the financial reporting process. The Saudi environment was selected for some reasons; 1) Saudi companies have recently adopted IFRS. 2) in an emerging market, like Saudi market, as noted by Jaggi and Tsui (1999), it will be beneficial to both international and domestic investors in understanding the causes of delays in the release of audit reports. The audit report delay is a particularly critical factor in emerging and newly developed capital markets where the audited financial statements in the annual report are the only reliable source of information available to investors (Leventis et al., 2005). 3) In an environment such as the Saudi environment which is characterized as highly secret, in accordance with the classification of Hofsted's cultural values, timeliness considers to be more important to compensate for the low level of disclosure. Thus, the audit report delay should be given attention in respond to the Saudi government's inspiration to attract the foreign investment and encouraging the local companies to involve in the free market strategies.

Therefore, this research use data from Saudi listed companies to answer the following questions:

\section{What is the impact of audit committee characteristics on audit report lag?}

1. What is the impact of IFRS on audit report lag?

2. What is the impact of IFRS on audit committee quality?

3. What is the impact of IFRS on the association between audit committee and audit report lag?

To answer the previous questions, the data for 99 Saudi non-financial companies was collected over the years from 2015 to 2018. This period covers two stages, first one before mandatory adoption of IFRS over two years 2015 and 2016 , and second stage after adoption of IFRS over two years 2017 and 2018. The results of panel Poisson regression, based on a sample of 396 firm-year observations- reveal that only audit committee financial experience has a significant association with audit report lag. Concerning IFRS, the results showed that it strongly influenced the context of audit delay, where it influenced audit report lag, audit committee quality and the association between them. The findings of this research should be of interest not only to academic researchers interested in examining the uniqueness of auditing issues in a country, but also to practitioners and policy makers in Saudi Arabia and other Middle-Eastern and developing countries sharing similar socio-economic environment. Regulators need to understand the causes of the audit report lag before they can legislate effectively to reduce it. Also, the results provide useful insight concerning how IFRS influence Saudi financial reporting environment.

The paper proceeds as follows; next section present a literature and hypotheses development, section 3 explain the methodology, and section 4 provides substantive test results and conclusion.

\section{2. literature and hypotheses development}

\section{1 audit committee characteristics and audit report lag}

The expectation that audit committees exercise an active monitoring of the company financial reporting process is well established, and this role has been confirmed by many CG codes and professional pronouncements (Song \& Windram, 2004). The audit committee is now being viewed as a principal player in the effort to implement governance reforms and to rebuild public confidence in financial reporting. Also, the strong corporate governance (including an effective audit committee) has the 
potential to increase audit effectiveness and efficiency (Cohen \& Hanno, 2000). In this concern, the audit committee quality is expected to provide assistance in resolving conflicts with management and to lead to some improvement in overall audit quality (Karamanou \& Vafeas, 2005). To identify the concept of audit committee quality, prior literature indicates that the effectiveness of an audit committee is dependent on some characteristics (Davidson et al., 2005; Bédard \& Gendron, 2010). This paper presents the hypothesised association between audit reports lag and four audit committee quality characteristics below.

\section{Audit committee size}

Saudi capital market requires a listed company to appoint an audit committee that must be composed of not fewer than three members. Potential problems in the financial reporting process are more likely to be uncovered and resolved with a larger audit committee, where a larger committee size increases the resources available to the audit committee and improves the quality of oversight (Mohd Ghazali, 2014). Li et al. (2008) and Persons (2009) show that the audit committee size influences corporate disclosures, and Ahmad-Zaluki and Wan-Hussin (2010) provide weak evidence that audit committee size is positively associated with the quality of financial information disclosure. However, most of the studies reviewed by Bédard and Gendron (2010) indicated that size of the audit committee is not an important determinant of effectiveness, and they caution that the incremental costs of poorer communication, coordination, involvement and decision making associated with a larger audit committee might outweigh the benefits. Apadore and Noor (2013) found that Audit committee size is significantly associated with audit report lag, while Akinleye and Aduwo (2019) revealed that there is no significant association between AC size and audit report lag. In the context of current study, it can be argued that large audit committee can perform its duties in effective way. So, it can be expected that larger audit committee lead to reduce audit report lag. Therefore, the following hypothesis is proposed:

\section{$\mathrm{H}_{1}$ : There is a negative association between audit committee size and audit report lag.}

\section{Audit committee independence}

According to the agency theory, the independent members in audit committee could help the principals to monitor the agents' activities and reduce benefits from withholding information (Goodman, et al. 2013), so independence consider an important factor for improvement the AC quality (Carcello, et al. 2011). The importance of independent directors is stem from the fact that they are in better position to control because their indirectly affiliated with management (Brandes et al. 2016). One of the objectives of the audit committee is to give unbiased reviews on financial information, and some studies have documented that audit committee independence can contribute to the quality of financial reporting (DeZoort et al., 2003; García Lara et al., 2014; Chen et al., 2018). Krishnan (2005) finds that independent audit committees are significantly less likely to be associated with the incidence of internal control problems over financial reporting. A meta-analysis conducted by Pomeroy and Thornton (2008) of studies on audit committee independence and financial reporting quality concludes that the independence of the audit committee has more impact in enhancing audit quality through averting going concern reports and auditor resignations than it is at enhancing accruals quality and avoiding restatements. A more extensive review on the audit committee literature by Bédard and Gendron (2010) supports the view that independent audit committees contribute positively to the financial reporting process, which motivates the following hypothesis:

\section{$\mathrm{H}_{2}$ : There is a negative relationship between audit committee independence and audit report lag.}

\section{Audit committee meeting}

The audit committee meeting is the place for directors to discuss the financial reporting process and it is where the process of monitoring financial reporting occurs, so audit committee meetings are considered as an important tool in ensuring audit committee members are fulfilling their responsibilities towards the company. It can be argued that an independent audit committee is unlikely to be effective unless the committee is also active (Menon \& Williams, 1994). Raghunandan et al. (1998) and Abbott et al. (2003a and 2003b) argue that by meeting frequently, the audit committee will remain informed and knowledgeable about accounting or auditing issues and can direct internal and external audit resources to address the matter in a timely fashion. So, audit committee must carry out activities effectively through increased frequency of meetings in order to maintain its control functions (Bedard et al., 2004). During the audit committee meeting the problems encountered in the financial reporting process are identified, but if the frequency of the meetings is low the problems may not be rectified and resolved within a short period of time. Thus, it is predicted that a company that has a higher number of audit committee meetings will have a shorter audit lag. However, Bédard and Gendron (2010) showed that most of the studies on audit committee meeting and financial reporting quality that they reviewed do not find significant associations. In the context of the current study, the following hypothesis can be examined;

\section{$\mathrm{H}_{3}$ : There is a negative association between number of audit committee meetings and audit report lag.}


Audit committees are responsible for numerous duties that require a high degree of accounting sophistication, so, Audit committee financial expertise is important in order to effectively dealing with these responsibilities. DeZoort et al. (2003) note that audit committee members with experience in financial reporting and auditing especially those who are CPAs would understand auditors' tasks and responsibilities. They would become more supportive of the auditors compared to audit committee members who do not have similar experience. Audit committee members who are experts are more 'friendly' with the auditors, comprehensible, logical and coherent when they are discussing with the auditors regarding the financial reporting of the company. Previous studies show that the fraudulent financial reporting companies have few members that have expertise in accounting (McMullen \& Raghunandan, 1996; Beasley, et al. 1999). Xie et al. (2003), Abbott et al. (2004) and Bédard et al. (2004) document that audit committee financial expertise reduces financial restatements or constrains the propensity of managers to engage in earnings management. Krishnan (2005) and Zhang, et al. (2007) find that firms are more likely to be identified with deficiencies in internal control over financial reporting if their audit committees have less financial expertise. These studies suggest that financially knowledgeable audit committee members are more helpful to external auditors. Thus, the following hypothesis is offered:

\section{$\mathrm{H}_{4}$ : There is a negative relationship between audit committee financial expertise and audit report lag.}

\subsection{IFRS and the association between audit committee and timelines}

The adoption of IFRS attracts much attention in accounting literature, where the wider adoption of IFRS worldwide has provided researchers an opportunity to examine the impact of accounting standards in different legal, institutional and economic settings (Onulaka, 2014; DeGeorge et al. 2016). Generally, the adoption of IFRS will affect the company, where it allows companies more flexibility in the choice of accounting policies (Yurisandi \& Puspitasari, 2015). This flexibility in the choice and changing accounting policies is linked to the qualitative characteristics of information, as one of the important justifications for managers when selecting or changing policies is to influence those characteristics (Nobes \& Stadler, 2015). Of qualitative characteristics, timeliness is considered to be an important feature of the quality of the financial reporting (Sultana et al. 2015; Abbott et al. 2012). Thus, it is expected that IFRS could influence audit delay and consequently timeliness of financial reports. In this context, despite Oussii and Boulila Taktak, (2018) argued that the adoption of IFRS is expected to reduce audit delays and provide more readable financial statements within the regulatory time period, Ahmed et al. (2013) indicated that IFRS is complicated as it is heavily used fair value accounting, hence it increases reporting lag. Also, IFRS require more detailed disclosure, and preparation of financial statements is influenced by disclosure requirements (Stovall, 2010), thus the workload of the auditor is expected to increase as the financial statements are complex (Amirul \& Md Salleh, 2014). Most of the auditing literature indicated that the adoption of IFRS resulted in the increasing of the auditors' efforts (Emadfallatah et al., 2019). IFRS adoption has attracted the attention of empirical studies to explore whether the adoption improves the quality and timeliness of the financial reporting (Khlif \& Achek, 2016). In this context, yacoob \& Ahmad, (2011) found that the application of IFRS leads to the delayed issuance of financial statements reflecting a decrease in the timing property. (Najihah \& Ayoib, 2011, 2012) and Amirul \& Md Salleh (2014) found that the adoption of IFRS increases the audit time for Malaysian companies, and Also, Habib and Bhuiyan (2011) found that the adoption of IFRS increases the audit report lag in New Zealand except for industry specialized auditors.

On the other hand, the difficulties of adoption IFRS are not only in accounting treatments but also in the difficulty of adhering to more detailed disclosure requirements (Berhunt, 2008; Griffin, et al. 2009). Khlif and Achek, (2016) argued that IFRS require auditors to understand managerial judgments concerning recognition rules and categorization when performing audit tasks. Therefore, the adoption of IFRS and accompanying difficulties may face the company in implementation and the complexities and disclosure requirements that are related to IFRS drives the company to improve the efficiency of the Audit Committee as one of the mechanisms that help in dealing with these difficulties and facilitate the work of the auditor. Consequently, it can be expected that IFRS adoption improves audit committee quality. In addition, the adoption of IFRS affects the variables associated with the financial reporting process and indirectly affects the relationships between those variables, where Nadhir and Wardhani (2019) argued that IFRS influence the relation between audit quality and earnings quality. In this context, the expected impact of IFRS on both the audit delay and the Audit Committee quality leads to an impact on the nature and strength of the relationship between the quality characteristics of the Audit Committee and the Audit Report lag. Accordingly, it can be argued that IFRS could influence audit delay, audit committee quality and the relation between audit committee characteristics and audit report lag. Therefore, the following hypotheses will be examined:

$\mathrm{H}_{5}:$ There is a positive association between IFRS and audit report lag.

$\mathrm{H}_{6}$ : There is a positive association between IFRS and audit committee quality.

$\mathrm{H}_{7}$ : IFRS adoption influences the relation between audit committee characteristics and audit report lag. 


\subsection{Sample}

The Sample contains non-financial Saudi listed companies over the period between 2015 and 2018. Of 125 listed companies, a sample of 99 companies working in 16 sectors are selected due to incomplete or ambiguous data. The final sample contain 396 firm-year observations are examined.

\section{2 empirical models}

To examine the hypotheses concerning the impact of audit committee characteristics and IFRS on audit report lag, the following regression model will be used. The audit report lag model used in this study is adapted from prior studies to accommodate the audit committee quality variables, IFRS adoption variable and control variables.

$$
\begin{aligned}
& \text { ARL }=\beta_{0}+\beta_{1} \text { IFRS }+\beta_{2} \text { ACSIZE }+\beta_{3} \text { ACIND }+\beta_{4} \text { ACMEETING }+\beta_{5} \text { ACEXP }+\beta_{6} \text { BIG } 4+\beta_{7} \text { CSIZE }+\beta_{8} \text { Model } 1 \\
& \text { PROF }+\beta_{9} \text { LEV }+\beta_{10} \text { ACT }+£
\end{aligned}
$$

where:

$\begin{array}{ll}\text { ARL } & \text { Number of days from fiscal year end to the date of audit report } \\ \text { IFRS } & 1 \text { for adoption of IFRS, } 0 \text { otherwise } \\ \text { ACSIZE } & \text { Number of audit committee members } \\ \text { ACIND } & \text { Proportion of independent nonexecutive directors on audit committee } \\ \text { ACMEETING } & \begin{array}{l}\text { Number of audit committee meetings during a year } \\ \text { ACEXP }\end{array} \\ \begin{array}{l}1 \text { If audit committee has at least one member who have accounting or related financial management } \\ \text { expertise, } 0 \text { otherwise }\end{array} \\ \text { BIG4 } & 1 \text { if the auditor is PricewaterhouseCoopers, Ernst and Young, KPMG or Deloitte, } 0 \text { otherwise } \\ \text { CSIZE } & \text { Natural log of total assets } \\ \text { PROF } & \text { Net profit to total assets rate } \\ \text { LEV } & \text { Leverage } \\ \text { ACT } & 1, \text { if companies are industrial, and } 0 \text { otherwise }\end{array}$

To examine H7, the previous model is used for sample data before IFRS adoption and then used for data after adoption, and comparing the results. To examine H6, the following regression model will be used:

$$
\text { ACQUALITY }=\beta_{0}+\beta_{1} \text { IFRS }+\beta_{2} \text { BIG4 }+\beta_{3} \text { CSIZE }+\beta_{4} \text { PROF }+\beta_{5} \text { LEV }+\beta_{6} \text { ACT }+\epsilon
$$

Model 2

where

ACQUALITY aggregate measure for audit committee quality ranges from 0 to 4 according to the previous four

\section{Results} characteristics

\subsection{Descriptive statistics}

Table 1 presents the descriptive statistics of all variables investigated in this study. With regard to audit report lag, the minimum audit report lag is 21 days and maximum is 104 days. On average, Saudi listed companies take about 69 days to issue audit reports after the fiscal year ended. This average has significantly changed between before and after adoption of IFRS, as it is 66 days before IFRS adoption and 77 days after IFRS adoption. The audit lag for Saudi companies is shorter than what have been reported by other studies in other countries, such as 111 days in Nigerian companies (Ibadin, et al., 2012), 103 days in Malaysian companies (Hashim \& Abdul Rahman, 2011), 97 days in Greek companies (Leventis, et al., 2005), and 100 days in Malaysian companies (Apadore \& Noor, 2013), and it is close to 67 days in Egyptian companies (Afify, 2009). This is consistent with what have been documented by the study of Ball, et al (2000) which found that companies in jurisdictions that have a strong shareholder orientation - like Saudi environment- tend to provide earnings information sooner than companies in countries operating under a legal code system. The results indicate that the majority of Saudi companies adhere to the date stipulated by Saudi financial market Listing Requirement that the annual report shall be issued and submitted within a period not exceeding 3 months from the financial year end of the company. Such results reflect that the Saudi companies are concerned and realised that audited reports are useful for users' decision-making, which support the notion that excessive delay in publishing financial statements would increase uncertainty in relation to investment decisions (Ahmad \& Kamarudin, 2003; Hashim \& Abdul 
Rahman, 2011). With regard to audit committee characteristics, the minimum number of audit committee members is 2 and maximum number is 6 . The average number of audit committee members is 3.59 members, which is slightly lower than Ishak, et al., (2010), who document an average size of 3.86 people, and slightly bigger than Apadore and Noor, (2013) who document an average size of 3.28 people. Concerning independence of audit committees, about three quarters of audit committee members are independent directors (72\%), which is lower than what have been documented in Hashim \& Abdul Rahman, 2011 (93\%), and bigger than Mohamad-Nor, et al., 2010 (68\%). The number of audit committee meetings ranges from 1 to 12 meetings, and the average number of audit committee meetings is 4.5 times, which consistent with Mohd-Saleh et al. (2007) who show that the average number of audit committee meetings in 2001 was 4.2 times. The more frequently number of audit committee meetings is 4 times, and About $82 \%$ of the sample companies have at least four audit committee meetings during the year. In term of background on audit committees, on average about $65 \%$ of audit committee have at least one member who has knowledge in accounting or finance.

Table 1

Descriptive Statistics

\begin{tabular}{lccccc}
\hline Panel 1: continuous variables & & & & & \\
& $\mathrm{N}$ & Minimum & Maximum & Mean & Std. Deviation \\
\hline ARL & 396 & 21 & 104 & 69.05769 & 18.49716 \\
ACSIZE & 396 & 2 & 6 & 3.59 & 0.8052229 \\
ACMEETING & 396 & 1 & 12 & 4.535354 & 2.51653 \\
ACIND & 396 & 25 & 100 & 71.83576 & 18.76671 \\
ACQUALITY & 396 & 0 & 4 & 2.524752 & 1.063899 \\
CSIZE & 396 & 4.07 & 12.39 & 9.3298 & 2.38712 \\
PROF & 396 & -.25 & .414 & .2274 & 15.80233 \\
LEV & 396 & 2.14 & 9.97 & 4.9272 & 2.20407 \\
Panel 2: dummy variables & & & & & 1 \\
& & $139(35.1 \%)$ & & $257(64.9 \%)$ \\
ACEXP & & $168(42.4 \%)$ & & $228(57.6 \%)$ \\
ACT & & $167(42.2 \%)$ & & $229(57.8 \%)$ \\
BIG4 & & & & \\
\end{tabular}

\subsection{Correlation analysis}

To examine the univariate relation between IFRS, audit report lag and audit committee characteristics, the correlation test is conducted. Table 2 shows the Pearson Correlation results which show that of the audit committees' characteristics, only both the experience and independence of audit committee (ACEXP and ACIND) has a weak negative correlation with audit report lag (coef. -0.0136 and -0.1069). This negative correlation indicates that audit committee which have at least one member with a financial knowledge background and more independent directors can help to lower audit report lag. The results also indicate a strong positive correlation between IFRS and audit report lag, which indicate that the average time of audit completion is significantly increased after mandatory adoption of IFRS. In addition, the results showed a weak positive correlation between IFRS adoption and AC size, AC independence and aggregate quality of the audit committee. These results reflect the weak tendency of companies to strengthen the efficiency of the Audit Committee after the adoption of IFRS, where companies tend, to a limited degree, to increase the size of the Audit Committee and increase the proportion of independent directors.

Table 2

Correlation results

\begin{tabular}{|c|c|c|c|c|c|c|c|}
\hline & ARL & IFRS & ACSIZE & ACEXP & ACMEETING & ACIND & ACQUALITY \\
\hline ARL & 1.0000 & & & & & & \\
\hline IFRS & $0.4412 * *$ & 1.0000 & & & & & \\
\hline ACSIZE & 0.1000 & $0.0170^{*}$ & 1.0000 & & & & \\
\hline ACEXP & $-0.0136^{* *}$ & 0.1153 & 0.4542 & 1.0000 & & & \\
\hline ACMEETING & 0.0098 & 0.0460 & 0.2707 & $0.4778 *$ & 1.0000 & & \\
\hline ACIND & $-0.1069^{*}$ & $0.0665^{*}$ & $0.4195 *$ & 0.4159 & $0.3247 * *$ & 1.0000 & \\
\hline ACQUALITY & $-0.0733 * *$ & $0.0695^{*}$ & $0.5382 * *$ & $0.7966^{* *}$ & $0.4717 * *$ & $0.6836 * *$ & 1.0000 \\
\hline
\end{tabular}

* Correlation is significant at the 0.05 level (2 tailed).

** Correlation is significant at the 0.01 level (2-tailed). 
To examine the hypotheses, the regression analysis is conducted. Given that dependent variable (ARL or ACQUALITY) is count data, the regression analysis is conducted using Poisson regression (Long \& Freese, 2003). A likelihood ratio chi-squared statistic test (goodness of fit CHI2) is conducted to examine over-dispersion, and the results (not reported) show that Poisson distribution is appropriate. Panel data analysis is used to take the effect of the time into account. To examine the hypotheses H1 to H5, table 3 exhibits the Random-effects Poisson regression results of model 1. Concerning audit committee characteristics, the results show that only audit committee experience (ACEXP) has a significant negative association with audit report lag. This result is consistent with Hashim \& Abdul Rahman (2011), but not consistent with Apadore \& Noor, (2013); MohamadNor, et al., (2010). The result indicates that the financial background experience of the members of audit committees help to lower the period to issue the audit report, which support the hypothesis H4. Accounting experience is fundamental to enable the audit committee to understand and cater on the problematic issue on the financial reporting system of the company. This result is consistent with studies that investigated the impact of financial expertise on the efficiency of the Audit Committee and indicated that the accounting experience of the members of the Audit Committee affects the quality of the financial reporting (DeFond et al., 2005; Krishnan and Visvanathan, 2008; Dhaliwal et al., 2010; Abernathy et al., 2014). Neither of the other variables (audit committee size ACSIZE, audit committee meetings ACMEETING, and audit committee independence ACIND) is statistically significant. The other three hypotheses are rejected due to non-significant association with audit report lag.

Overall, these results refer to a very weak impact for audit committee characteristics on the timing of auditor report. Consequently, these results raise questions concerning the validity of such characteristics as determinants of audit committee quality, which the study of Bédard \& Gendron (2010) conclude that the effectiveness of audit committee practices may vary with "environmental factors such as concentration of ownership, enforcement level and exposure to lawsuits". In this context, Saudi environment is characterized by some distinctive features which are different from many other environments, Alrazeen \& Karbhari,(2004) argued that the Saudi Arabian environment resembles to some extent the environments of both the developed and developing countries. However, this result is consistent -to a large extent- with the results of previous studies that generally indicated to a weak association between audit committee characteristics and audit report lag. Although the insignificant association between audit committee size ACSIZE and audit report lag, the positive coefficient indicates that - contrary to what hypothesised- the lager audit committee associate with more delay of audit report. This result support the point of view that size of the audit committee is not an important determinant of effectiveness, which the incremental costs of poorer communication, coordination, involvement and decision making associated with a larger audit committee might outweigh the benefits (Bédard \& Gendron, 2010). Also, the insignificant association between ACMEETING and ARL is consistent with Bédard \& Gendron (2010) that shows that most of the studies on audit committee meeting and financial reporting quality that they reviewed do not find significant associations. Concerning audit committee independence, although the insignificant association, the negative coefficient is consistent with what hypothesised.

Concerning the impact of IFRS, the results show a significant positive association between IFRS and audit report lag reflecting the increasing of audit delay after mandatory adoption of IFRS, which lead to accept H5. This result supports the view of increasing the complexity of financial reporting process after adoption of IFRS.

Table 3

Regression results

\begin{tabular}{lcccc}
\hline ARL & Coef. & Std. Err. & $\mathrm{z}$ & $\mathrm{P}>|\mathrm{z}|$ \\
\hline IFRS & 0.1314853 & 0.1084747 & 1.21 & 0.022 \\
ACSIZE & 0.0289705 & 0.0199736 & 1.45 & 0.147 \\
ACEXP & -0.02308 & 0.0370994 & -0.62 & 0.005 \\
ACMEETING & 0.0025636 & 0.0077968 & 0.33 & 0.742 \\
ACIND & -0.0021798 & 0.0008311 & -2.62 & 0.109 \\
CSIZE & 0.0043473 & 0.0122068 & 0.36 & 0.722 \\
PROF & -0.0281211 & 0.0157711 & -1.78 & 0.075 \\
ACT & 0.007671 & 0.005299 & 1.45 & 0.014 \\
LEV & -0.0298984 & 0.0143805 & -2.08 & 0.038 \\
BIG4 & 0.0031256 & 0.0420659 & 0.07 & 0.941 \\
cons & 4.416479 & 0.1824927 & 24.20 & 0.000 \\
Wald chi2(10) & & 29.34 & & \\
Prob $>$ chi2 & & 0.0011 & & \\
Log likelihood & -448.76824 & & \\
Likelihood-ratio test of alpha $=0$ : chibar2(01) $=21.15$ & Prob $>=$ chibar2 $=0.000$ & & \\
\hline
\end{tabular}


To examine the impact of IFRS adoption on audit committee quality, Table 4 presents the Random-effects Poisson regression results of model 2, where the results show a positive significant association between IFRS and audit committee quality. This result reflects that the adoption of IFRS lead to increasing adoption of quality characteristics of audit committee, leading to accept H6. This result indicates that companies in the context of the transition to IFRS have been interested in the development of audit committees as the most governance mechanism related to the financial reporting process. To examine the impact of IFRS on the relation between audit committee characteristics and audit report lag, table 5 presents the regression results for model 1 before IFRS adoption and after adoption. Comparing the results before and after IFRS shows that to a large extent the adoption of IFRS affects the relationship, which leads to the acceptance of the hypothesis H7. The results show that of the four characteristics, three characteristics have changed their relation with audit lag, and that change is the shift from the insignificant relationship to the existence of a significant relationship.

Table 4

Regression results

\begin{tabular}{|c|c|c|c|c|}
\hline ACQUALITY & Coef. & Std. Err. & $\mathrm{Z}$ & $\mathrm{P}>|\mathrm{z}|$ \\
\hline IFRS & 0.1785722 & 0.2849481 & 1.63 & 0.053 \\
\hline CSIZE & 0.0110745 & 0.0556971 & 1.20 & 0.084 \\
\hline PROF & -0.0357465 & 0.0717389 & -0.50 & 0.618 \\
\hline $\mathrm{ACT}$ & 0.014792 & 0.0269517 & 0.55 & 0.583 \\
\hline LEV & 0.0165938 & 0.0588689 & 0.28 & 0.778 \\
\hline BIG4 & 0.0745621 & 0.2034457 & 1.37 & 0.071 \\
\hline cons & 0.9293859 & 0.7482417 & 1.24 & 0.021 \\
\hline Wald chi2(6) & & 11.58 & & \\
\hline Prob > chi 2 & & 0.0038 & & \\
\hline Log likelihood & & -463.50358 & & \\
\hline
\end{tabular}

Table 5

Comparison of the regression results

\begin{tabular}{|c|c|c|c|c|}
\hline \multirow[b]{2}{*}{ ARL } & \multicolumn{2}{|c|}{ Panel 1: before IFRS } & \multicolumn{2}{|c|}{ Panel 2: after IFRS } \\
\hline & Coef. & $\mathrm{P}>|\mathrm{z}|$ & Coef. & $\mathrm{P}>|\mathrm{z}|$ \\
\hline ACSIZE & -0.0265691 & 0.407 & -.0129688 & 0.062 \\
\hline ACEXP & -0.0852992 & 0.221 & -0.031327 & 0.094 \\
\hline ACMEETING & -.0125302 & 0.355 & .0092269 & 0.357 \\
\hline ACIND & .0024514 & 0.106 & -.0034972 & 0.000 \\
\hline CSIZE & .023465 & 0.113 & -.0683748 & 0.013 \\
\hline PROF & -.0180632 & 0.376 & -.0693736 & 0.009 \\
\hline ACT & .7136471 & 0.000 & .0077797 & 0.158 \\
\hline LEV & -.0586082 & 0.000 & -.0298681 & 0.132 \\
\hline BIG4 & .0405682 & 0.668 & .0061075 & 0.898 \\
\hline cons & 4.295138 & 0.000 & 5.585332 & 0.000 \\
\hline Wald chi2(9) & & & & \\
\hline Prob > chi 2 & & & & \\
\hline Log likelihood & -18 & & & \\
\hline
\end{tabular}

\section{Conclusion}

Timeliness of financial reporting is considered as an important attribute of good corporate governance identified by the OECD and World Bank. Various stakeholders- including shareholders- need timely information and delayed information becomes less value. This study provided an analysis to the impact of IFRS on audit delay and the role of governance mechanisms in the context of emerging markets that are characterized by weak regulatory environment and governance structures. The audit report delay ranges from 21 days to 104 days, and the average duration that needs by external auditor to issue audit report is 69 days. This average time for issuing financial reports consider to be lower than what have been found in other countries, which indicate that Saudi companies are more interested in providing timely financial reporting. Also, this result shows that the companies did comply with financial market Listing Requirement. The regression analysis results show that only audit committee expertise is mainly influencing audit report lag. However, the results also show that audit committee size, independence, and meeting, do not play crucial role in audit report lag. Therefore, it can be argued that the overall characteristics of audit committees are weakly 
influence audit report delay. These results raise some questions to various parties in Saudi business environment about the role of audit committees and their requirements. It can be argued that the framework of audit committee role and responsibilities in Saudi environment and other Arabic countries need to be revised. Regarding IFRS, the results showed that it has a strong impact on the context of audit committee and audit delay. IFRS adoption leads to increasing audit report lag, and increasing quality of audit committee. Also, IFRS influence the relation between audit committee characteristics and audit report lag, where that relationship has turned from insignificant association to significant association.

\section{References}

Abbott, L. J., Parker, S., \& Peters, G. F. (2004). Audit committee characteristics and restatements. Auditing: A Journal of Practice and Theory, 23(1), 69-87.

Abbott, L. J., Parker, S., Peters, G. F., \& Raghunandan, K. (2003a). The association between audit committee characteristics and audit fees. Auditing: A Journal of Practice and Theory, 22(2), 17-32.

Abbott, L. J., Parker, S., Peters, G. F., \& Raghunandan, K. (2003b). An empirical investigation of audit fees, nonaudit fees, and audit committees. Contemporary Accounting Research, 20(2), 215-34.

Abbott, L. J., Parker, S., Peters, G. F. (2012). Internal audit assistance and external audit timeliness. Auditing: A Journal of Practice \& Theory, 31(4), 3-20.

Abernathy, J.L., Beyer, B., Masli, A., \& Stefaniak, C. (2014). The association between characteristics of audit committee accounting experts, AC chairs, and financial reporting timeliness. Advances in Accounting, 30(2), 283-297.

Afify, H. A. E. (2009). Determinants of audit report lag: Does implementing corporate governance have any impact? Empirical evidence from Egypt. Journal of Applied Accounting Research, 10(1), 56-86.

Ahmad, R. A. R. \& Kamarudin, K. A. (2003), Audit delay and the timeliness of corporate reporting: Malaysian evidence, Working Paper, MARA University of Technology, Shah Alam.

Ahmed, K., Chalmers, K., Khlif, H. (2013). A meta-analysis of IFRS adoption effects. The International Journal of Accounting, $48(2), 173-217$.

Ahmad-Zaluki, N. A. \& Wan-Hussin, W. N. (2010). Corporate governance and earnings forecasts accuracy. Asian Review of Accounting, 18(1), 50-67.

Akinleye, G. T. \& Aduwo, O. O. (2019), Effect of audit committee characteristics on the timeliness of financial reporting in Nigeria. Journal of Economics, Management and Trade, 24(3), 1-10.

Al-Ajmi, J. (2008). Audit and reporting delays: Evidence from an emerging market. Advances in Accounting, 24(1), 217-226.

Almosa, S.A. \& Alabbas, M. (2008). Audit delay: Evidence from listed joint stock companies in Saudi Arabia, Working paper, King Khalid University.

Al-Razeen, A. \& Karbhari, Y. (2004). Interaction between compulsory and voluntary disclosure in Saudi Arabian corporate annual reports. Managerial Auditing Journal, 19(3), 351-360.

Amirul, S. M. \& Md Salleh, M. F. (2014), Convergence to IFRs and Audit Report Lag in Malaysia. Research Journal of Finance and Accounting, 5(23), 9-17.

Apadore, K. \& Noor, M. M., (2013), Determinants of audit report lag and corporate governance in Malaysia. International Journal of Business and Management, 8(15), 151-163.

Baatwah, S. R., Salleh, Z., \& Stewart, J., (2019). Audit committee chair accounting expertise and audit report timeliness: The moderating effect of chair characteristics, Asian Review of Accounting, https://doi.org/10.1108/ARA-12-2017-0190.

Ball, R., Kothari, S.P., \& Robin, A., (2000), the effect of international institutional factors on properties of accounting earnings. Journal of Accounting and Economics, 29(1), 1-51.

Beasley, M. S., Carcello, J. V., \& Hermanson, D. R. (1999), Fraudulent financial reporting: 1987-1997, an analysis of US public companies: research report, NY: Committee of Sponsoring Organizations, https://egrove.olemiss.edu/aicpa assoc/249/.

Bédard, J. \& Gendron, Y. (2010), Strengthening the financial reporting systems: Can audit committees deliver?, International Journal of Auditing, 14(2), 1-37.

Bédard, J., Chtourou, S. M., \& Courteau, L. (2004), The effect of audit committee expertise, independence, and activity on aggressive earnings management. Auditing: A Journal of Practice \& Theory, 23(2), 13-35.

Bernhut, S. (2008). Global Standards. CA Magazine, 141, 24-28.

Bonson-Ponte, E., Escobar-Rodriguez, T., \& Borrero-Dominguez, C. (2008), Empirical analysis of delays in the signing of audit reports in Spain. International Journal of Auditing, 12(2), 129-140.

Brandes, P., Dharwadkar, R., \& Suh, S. (2016), I know something you don't know!: The role of linking pin directors in monitoring and incentive alignment. Strategic Management Journal, 37(5), 964-981.

Carcello, J. V., Hermanson, D. R., \& Ye, Z. (2011). Corporate governance research in accounting and auditing: Insights, practice implications, and future research directions. Auditing: A Journal of Practice \& Theory, 30(3), $1-31$.

Chan, K.H., Luo, V.W., \& Mo, P.L.L. (2016). Determinants and implications of long audit reporting lags: evidence from China. Accounting and Business Research, 46(2), 145-166.

Chen, F., Hope, O. K., Li, Q., \& Wang, X. (2018), Flight to quality in international markets: Political uncertainty and investors' demand for financial reporting quality. Contemporary Accounting Research, 35(1), 117-155. 
Cohen, J. \& Hanno, D. (2000). Auditors' consideration of corporate governance and management control philosophy in preplanning and planning judgments. Auditing: A Journal of Practice \& Theory, 19, 133-46.

Davidson, R., Goodwin-Stewart, J., \& Kent, P. (2005). Internal governance structures and earnings management. Accounting and Finance, 45, 241-67.

DeFond, M.L., Hann, R.N., \& Hu, X. (2005), Does the market value financial expertise on audit committees of boards of directors?, Journal of Accounting Research, 43(2), 153-193.

De George, E. T., Li, X., \& Shivakumar, L. (2016). A review of the IFRS adoption literature. Review of Accounting Studies, 21(3), 898-1004.

DeZoort, F.T., Hermanson, D. R., \& Houston, R. W. (2003). Audit committee support for auditors: the effect of materiality justification and accounting precision. Journal of Accounting and Public Policy, 22, 175-199.

Dhaliwal, D., Naiker, V., \& Navissi, F. (2010). The association between accruals quality and the characteristics of accounting experts and mix of expertise on audit committees. Contemporary Accounting Research, 27(3), 787-827.

Durand, G. (2019). The determinants of audit report lag: a meta-analysis. Managerial Auditing Journal, 34(1), 44-75.

Emadfallatah, Saat, N. A. B. M., Shah, S. B. M., \& Chong, C. W. (2019). IFRS Adoption and auditing issues - review paper. International Journal of Economics, Commerce and Management, 7(4), 498-518.

Ettredge, M. L., Li, C., \& Sun, L. (2006), The impact of SOX Section 404 internal control quality assessment on audit delay in the SOX era. Auditing: A Journal of Practice and Theory, 25(1), 1-23.

García Lara, J. M., García Osma, B., \& Penalva, F. (2014), Information consequences of accounting conservatism. European Accounting Review, 23(2), $173-198$.

Goodman, T. H., Neamtiu, M., Shroff, N., \& White, H. D. (2013). Management forecast quality and capital investment decisions. The Accounting Review, 89(1), 331-365.

Griffin, P. A., Lont, D. H., \& Sun, Y. (2009). Governance regulatory changes, IFRS adoption, and New Zealand audit and nonaudit fees: Empirical evidence. Accounting \& Finance, 49(4), 697-724.

Habib, A. (2015). The new Chinese accounting standards and audit report lag. International Journal of Auditing, 19(1), 1-14.

Habib, A. \& Bhuiyan, M.B.U. (2011). Audit firm industry specialization and the audit report lag. Journal of International Accounting, Auditing and Taxation, 20, 32-44.

Habib, A., Bhuiyan, M. B. U., Huang, H. J., \& Miah, M. S. (2019). Determinants of audit report lag: A meta-analysis. International journal of auditing, 23(1),20-44.

Habib, A. \& Muhammadi, A. (2018). Political connections and audit report lag: Indonesian evidence. International Journal of Accounting \& Information Management, 26(1), 59-80.

Hashim, J. \& Abdul Rahman, R. (2011). Audit report lag and the effectiveness of audit committee among Malaysian listed companies. International Bulletin of Business Administration, 10, 50-61.

Ibadin, L. M., Izedonmi, F., \& Ibadin, P. O. (2012), The association between selected corporate governance attributes, company attributes and timeliness of financial reporting in Nigeria. Research Journal of Finance and Accounting, 3(9), 137-144.

Ishak, I., MuhamadSidek, A. S., \& Rashid, A. A. (2010). The Effect of company ownership on the timeliness of financial Reporting: Empirical evidence from Malaysia. UNITAR e-Journal, 6(2), 20-35.

Karamanou, I. \& Vafeas, N. (2005), The association between corporate boards, audit committees, and management earnings forecasts: an empirical analysis. Journal of Accounting Research, 43(3), 453-86.

Khoufi, N. \& Khoufi, W. (2018). An empirical examination of the determinants of audit report delay in France. Managerial Auditing Journal, 33(8/9), 700-714.

Khlif, H. \& Achek, I. (2016). IFRS adoption and auditing: a review. Asian Review of Accounting, 24(3), 338-361.

Krishnan, J. (2005). Audit committee quality and internal control: An empirical analysis. The Accounting Review, 80(2), 649675.

Krishnan, J. \& Yang, J. S. (2009). Recent trends in audit report and earnings announcement lags. Accounting Horizons, 23(3), 265-288.

Krishnan, G.V. \& Visvanathan, G. (2008), Does the SOX definition of an accounting expert matter? The association between audit committee directors' accounting expertise and accounting conservatism. Contemporary Accounting Research, 25(3), 827-857.

Lee, H., Mande, V., \& Son, M. (2008), A comparison of reporting lags of multinational and domestic firms. Journal of International Financial Management and Accounting, 19(1), 28-56.

Lee, H., Mande, V., \& Son, M. (2009), Do lengthy auditor tenure and the provision of non-audit services by the external auditor reduce audit report lags?, International Journal of Auditing, 13, 87-104.

Leventis, S., Weetman, P., \& Caramanis, C. (2005), Determinants of audit report lag: Some evidence from the Athens Stock Exchange. International Journal of Auditing, 9(1), 45-58.

Li, J., Pike, R., Haniffa, R. (2008), Intellectual capital disclosure and corporate governance structure in UK. Accounting and Business Research, 38(2), 136-159.

Long, J.S. \& Freese, J., (2003). Regression Models for Categorical Dependent Variables Using Stata. revised ed. Stata press, college station, TX. 
McMullen, D. A. \& Raghunandan, K. (1996). Enhancing audit committee effectiveness. Journal of Accountancy, $182(2)$, 7-81.

Menon, K. \& William, J. D. (1994), The usage of audit committees in monitoring. Journal of Accounting and Public Policy, 13(2), 121-139.

Mohammed, I. A., Che-Ahmad, A., \& Malek, M., (2018), IFRS Adoption and Audit Delay: The Role of Shareholders in the Audit Committee. International Journal of Accounting and Financial Reporting, 8(1), 325-343.

Mohamad-Nor, M. N., Shafie, R., \& Wan-Hussin, W. N., (2010), Corporate governance and audit report lag in Malaysia. Asian Academy of Management Journal of Accounting and Finance (AAMJAF), 6(2), 57- 84.

Mohd Ghazali, N. A. (2014). Board of directors and performance of Malaysian companies. International Journal of Managerial and Financial Accounting, 6(2), 117-132.

Mohd-Saleh, N., Mohd-Iskandar, T., \& Rahmat, M. M. (2007). Audit committee characteristics and earnings management: Evidence from Malaysia. Asian Review of Accounting, 15(2), 147-163.

Musa, A., (2019). the role of IFRS on financial reporting quality and global convergence: a conceptual review. International Business and Accounting Research Journal, 3(1), 67-76.

Nadhir, Z. \& Wardhani, R. (2019), The effect of audit quality and degree of international financial reporting standards (IFRS) convergence on the accrual earnings management in Asian countries. Entrepreneurship and Sustainability Issues, 7(1), 105-120.

Najihah, M.Y., \& Ayoib, C.A. (2011). IFRS adoption and audit timeliness: Evidence from Malaysia. Journal of American Academy of Business, 17(1), $112-118$.

Najihah, M.Y., \& Ayoib, C.A. (2012). Adoption of FRS 138 and audit delay in Malaysia. International Journal of Economics and Finance, 4(1), $167-178$.

Nobes, C. \& Stadler, C. (2015). The qualitative characteristics of financial information, and managers' accounting decisions: evidence from IFRS policy changes. Accounting and Business Research, 45(5), 572-601.

Odia, J.O. \& Ogiedu, K.O. (2013). IFRS Adoption: Issues, challenges and lessons for Nigeria and other adopters. Mediterranean Journal of Social Sciences, 4(3), 389.

Onulaka, P. N. (2014). Impact of Adoption of IFRS in Nigeria Capital Market, Preparers of Financial Statements and Auditors. International Journal of Science and Research, 3(11), 149-158.

Oussii, A. A., \& Boulila Taktak, N. (2018), Audit committee effectiveness and financial reporting timeliness: The case of Tunisian listed companies. African Journal of Economic and Management Studies, 9(1), 34-55.

Owusu-Ansah, S. (2000). Timeliness of corporate financial reporting in emerging capital markets: empirical evidence from the Zimbabwe Stock Exchange. Accounting and Business Research, 30(3), 241-254.

Persons, O. S. (2009). Audit committee characteristics and earlier voluntary ethics disclosure among fraud and no-fraud firms. International Journal of Disclosure and Governance, 6(4), 284-297.

Pomeroy, B. \& Thornton, D. (2008). Meta-analysis and the accounting literature: The case of audit committee independence and financial reporting quality. European Accounting Review, 17, 305-330.

Pope, P.F. \& McLeay, S.J. (2011). The European IFRS experiment: Objectives, research challenges and some early evidence, Accounting and Business Research, 41(3), 233-266.

Ragunadhan, K. R., Rama, D. V., \& Scarbrough, D. P. (1998). Accounting and auditing knowledge level of Canadian audit committee: Some empirical evidence. Journal of International Accounting, Auditing and Taxation, 7(2), $181-194$.

Rusmin, R. \& John, E. (2017). Audit quality and audit report lag: case of Indonesian listed companies. Asian Review of Accounting, 25(2), 191-210.

Sharma, D.S., Tanyi, P.N., \& Litt, B.A. (2017), Costs of mandatory periodic audit partner rotation: evidence from audit fees and audit timeliness. Auditing: A Journal of Practice \& Theory, 36(1), 129-149.

Song, J. \& Windram, B. (2004), Benchmarking audit committee effectiveness in financial reporting. International Journal of Auditing, 8, 195-205.

Stovall, D. C. (2010), Transition to IFRS: What can we learn?, The Business Review, Cambridge, 16(1), 120-126.

Sultana, N., Singh, H., Van der Zahn, J.-L. W. M. (2015), Audit committee characteristics and audit report lag. International Journal of Auditing, 19. $72-87$.

Xie, B., Davidson, W. N., \& Dadalt, P. J. (2003), Earnings management and corporate governance: The role of the board and the audit committee. Journal of Corporate Finance, 9(3), 295-316.

Yaacob, N. M., \& Che-Ahmad, A. (2011), IFRS adoption and audit timeliness: Evidence from Malaysia. The Journal of American Academy of Business, 17(1), 112-118.

Yurisandi, T., \& Puspitasari, E. (2015). Financial Reporting Quality - Before and After IFRS Adoption Using NiCE. Qualitative Characteristics Measurement, Behavioral Sciences, 211, 644-652.

Zhang, Y., Zhou, J., Zhou, N. (2007), Audit committee quality, auditor independence, and internal control weaknesses. Journal of Accounting and Public Policy, 26(3), 300-327. 
(c) (1)

(C) 2020 by the authors; licensee Growing Science, Canada. This is an open access article distributed under the terms and conditions of the Creative Commons Attribution (CC-BY) license (http://creativecommons.org/licenses/by/4.0/). 